\title{
Assessment of Knowledge, Attitude, and Practice Toward COVID-19 in China: An Online Cross-Sectional Survey
}

\author{
Yaqing Fang, ${ }^{*}$ Panpan Liu, and Qisheng Gao \\ School of Public Health, Hangzhou Medical College, Hangzhou, China
}

\begin{abstract}
To analyze the level of knowledge, attitude, and practice about COVID-19 among Chinese residents, noninterventional and anonymous survey was carried out with an online questionnaire. Among the survey respondents ( $n=619$ ), $59.9 \%$ were female, $61.1 \%$ were from 18 to 30 years of age, and $42.3 \%$ held an undergraduate's degree. The mean scores for each scale were as follows: perceived knowledge (36.3 \pm 6.1$)$, attitude (29.4 \pm 4.7$)$, practice (44.1 \pm 4.8$)$, total score (109.7 \pm 13.2$)$, barrier (0.2 \pm 0.7$)$, and cognition and behavior change score (8.5 \pm 1.4$)$. Perceived knowledge, attitude, practice, total score, and cognition and behavior changes were significantly and positively correlated, whereas barrier was negatively correlated with those scales $(P<0.001)$. Linear regressions revealed that those respondents who were medical professionals, civil servants, employees of state-owned enterprises and public institutions, and had relatively higher level of education were associated with a higher perceived knowledge score, attitude score, practice score, and total score. Higher mean cognition and behavior change score was associated with company employees $(8.8 \pm 1.3)$. More than half of the respondents $(51.4 \%)$ were optimistic about the government's interventional measures. The respondents in China had good knowledge, positive attitude, and active practice toward COVID-19, yet, it is advisable to strengthen nationwide publicity and focus on the target undereducated population by means of We-Chat, microblog, website, and community workers for better control effect.
\end{abstract}

\section{INTRODUCTION}

COVID-19, caused by SARS-CoV-2, was declared as a global health emergency by the WHO on January $30,2020 .^{1}$ The outbreak of COVID-19 was wreaking havoc worldwide due to strong infectiousness, virus mutation, and inadequate risk assessment regarding the urgency of the situation. It was regarded as a pandemic by the WHO on March 11, 2020. ${ }^{2}$ The COVID-19 pandemic has made tremendous impact on the whole world, with 1,699,595 confirmed cases of COVID-19, including 106,138 deaths globally as of 2:00 AM CEST, April $12,2020 .^{3}$ China, one of the seriously hit countries, had reported 82,160 confirmed cases, with 3,341 deaths up to April 12, 2020. ${ }^{4}$ The clinical symptoms of COVID-19 include fever, cough, shortness of breath, muscle ache, confusion, headache, sore throat, rhinorrhea, chest pain, diarrhea, nausea, and vomiting. ${ }^{5}$ Case fatality rates were $9.3 \%$ in Italy, $6.2 \%$ in Spain, $4.2 \%$ in France, ${ }^{6}$ and $2.3 \%$ in China. ${ }^{7}$

The outbreak of COVID-19 has captured the world's attention because it has the potential to cause severe political, social, and economic upheaval; therefore, it calls for great international concern and collaborative efforts of all countries to prevent the serious spread of COVID-19. Faced with the rapid growth of cases, the Chinese authorities have implemented prompt response measures, initiating public health level 1 response of 31 provinces, strict exit screening, cancellation of mass gatherings, and postponing all kinds of school from January 23, 2020 on. ${ }^{8}$ Meanwhile, the perceptions of communities toward this outbreak have become one of the hotspots, and several studies have been carried out, showing that the effectiveness of the government interventional measures depended a lot on people's adherence to these control measures, which was

*Address correspondence to Yaqing Fang, School of Public Health, Hangzhou Medical College, No. 481, Binwen Rd., Binjiang District, Hangzhou 310053, China. E-mail: colourwind1035@126.com influenced by their knowledge, attitude, and practice toward COVID-19 to a great extent. 9,10 Experience from SARS and Middle East respiratory syndrome indicated that the perceived cognition toward the outbreak was associated with the behavior, thus affecting the prevention and control of the disease. ${ }^{11,12}$ Public cooperation is crucial in containing the spread of COVID-19 and fighting against the pandemic calls for sustained efforts and constant vigilance. To promote interventional progress amid the coronavirus outbreak, there is an urgent need for assessment of the population's perceptions; hence, we investigated the perceived knowledge, attitude, and practice toward COVID-19 and the behavior changes before and after government measures in China.

\section{METHODS}

Survey design. This was a noninterventional, anonymized, self-administered, web-based survey of the knowledge, attitude, and practice of Chinese residents. This study was carried out from February 21, 2020 to March 18, 2020 using an online questionnaire.

Survey sample. To test the reliability and validity of a questionnaire that was designed by the author group, 30 participants took part in a preliminary experiment. Then, given the circumstance of strict exit screening and household quarantine of the COVID-19 outbreak, the formal online questionnaire (https://www.wjx.cn/newwjx/design/ sendqstart.aspx?activity=58583407) has been sent to 800 Sina microblog users nationwide by convenience sampling, ${ }^{13}$ among whom 619 completed it. Sina blog is one of the most popular blogs in China, and active users reach 550 million monthly, making it representative of online sampling, compared with the whole 904 million population of netizen. ${ }^{14}$ The response rate was about $77.4 \%$, which guaranteed for bivariate and multivariable analyses to be carried out. 
TABLE 1

Characteristics of the respondents $(N=619)$

\begin{tabular}{|c|c|c|c|}
\hline Characteristic & Categories & $N$ & $\%$ \\
\hline \multirow[t]{2}{*}{ Gender } & Male & 248 & 40.1 \\
\hline & Female & 371 & 59.9 \\
\hline \multirow[t]{6}{*}{ Age-group (years) } & $<18$ & 38 & 6.1 \\
\hline & $18-30$ & 378 & 61.1 \\
\hline & $31-40$ & 54 & 8.7 \\
\hline & $41-50$ & 83 & 13.4 \\
\hline & $51-060$ & 42 & 6.8 \\
\hline & $>60$ & 24 & 3.9 \\
\hline \multirow{3}{*}{ Living district } & City & 204 & 33.0 \\
\hline & Town & 163 & 26.3 \\
\hline & Village & 252 & 40.7 \\
\hline \multirow[t]{9}{*}{ Occupation } & Medical professionals & 38 & 6.1 \\
\hline & $\begin{array}{l}\text { Civil servants/employees of state-owned } \\
\text { enterprises and public institutions }\end{array}$ & 69 & 11.1 \\
\hline & Company employees & 79 & 12.8 \\
\hline & Workers & 44 & 7.1 \\
\hline & Farmers & 49 & 7.9 \\
\hline & Self-employed & 59 & 9.5 \\
\hline & Retired staff & 37 & 6.0 \\
\hline & Students & 211 & 34.1 \\
\hline & Others & 33 & 5.3 \\
\hline \multirow[t]{2}{*}{ Marital status } & Married & 311 & 50.2 \\
\hline & Unmarried & 307 & 49.6 \\
\hline \multirow[t]{6}{*}{ Level of education } & Primary school or below & 24 & 3.9 \\
\hline & Junior high school & 61 & 9.9 \\
\hline & Senior high school/technical secondary school & 79 & 12.8 \\
\hline & Junior college & 169 & 27.3 \\
\hline & Undergraduate & 262 & 42.3 \\
\hline & Post-undergraduate & 24 & 3.9 \\
\hline \multirow[t]{5}{*}{ Family members } & 1 & 1 & 0.2 \\
\hline & 2 & 15 & 2.4 \\
\hline & 3 & 161 & 26.0 \\
\hline & 4 & 234 & 37.8 \\
\hline & $\geq 5$ & 208 & 33.6 \\
\hline
\end{tabular}

Survey questionnaire. The questionnaire items were designed by the authors mainly based on the information and basic protective measures acquired from the National Health Commission of the People's Republic of China, the Chinese $\mathrm{CDC}$, the WHO, and various websites of Chinese government agencies, official media, as well as some previous studies as of February 16, 2020. ${ }^{15,16}$ In the pre-investigation, researchers screened all items and created the formal questionnaire through exploratory factor analysis using IBM SPSS Statistics for Windows version 23.0. The formal questionnaire was composed of seven different sections: 1) Sociodemographic characteristics: gender, age, province, living district, occupation, marital status, level of education, family members. 2) Questions related to perceived knowledge about COVID-19. 3) Questions related to attitude toward COVID-19. 4) Questions related to practice in preventing and controlling COVID-19. 5) Questions related to the overall evaluation of knowledge, attitude, and behavior toward COVID-19. 6) Questions related to the barriers for poor knowledge and insufficient protective measures. 7) Questions related to the cognition changes before and after government measures, and expectations about the government measures. Cronbach's alphas for the knowledge, attitudes, and clinical practice pattern scales were 0.940, 0.944, and 0.812, respectively. The overall scale had a high Cronbach's alpha coefficient (0.935).

Score measurement. Perceived knowledge score was assessed by eight questions evaluating 1) the level of knowledge regarding the possible hosts of SARS-CoV-2,2) the level of knowledge regarding the transmission routes of COVID-19,
3) the level of knowledge regarding the infectiousness of asymptomatic COVID-19 patients, 4) the level of knowledge regarding the symptoms of COVID-19,5) the level of knowledge regarding medical quarantine requirements for COVID-19, 6) the level of knowledge regarding susceptible population of COVID-19, 7) the level of knowledge regarding inactivation methods of SARS-CoV2 , and 8) the level of knowledge regarding the availability of specific drugs and vaccines for COVID-19.

Attitude score was evaluated by six questions assessing if respondents 1) keep themselves updated about COVID-19, 2) are willing to learn more about COVID-19, 3) are ready for strong supports and active cooperation in the prevention and control for COVID-19, 4) think the outbreak of COVID-19 should be taken seriously, 5) are aware of the designated hospitals in the area, and 6) have full confidence in the government's interventions.

Practice score was evaluated by 10 questions about 1) the frequency of wearing a mask when going out in a correct way, 2) the frequency of washing hands correctly, 3) the frequency of covering the nose and mouth with hands when sneezing or coughing, 4) the frequency of avoiding meeting and gathering, 5) the frequency of taking physical exercise, 6) the frequency of having a balanced and nutritious diet and less or no consumption of wild animals, 7) the frequency of avoiding contact with live poultry, 8) the frequency of paying attention to household hygiene and disinfection, 9) the frequency of getting enough sleep, and 10) whether or not going to the designated hospital immediately for medical treatment in case of cough, fever, dyspnea, and other suspected symptoms. 
TABLE 2

Scores of perceived knowledge $(N=619)$

\begin{tabular}{|c|c|c|c|c|}
\hline Detailed questions about perceived knowledge & Categories & $\mathrm{N}$ & $\%$ & $\mathrm{M} \pm \mathrm{SD}$ \\
\hline \multicolumn{5}{|l|}{ Your level of knowledge regarding } \\
\hline \multirow{5}{*}{ The possible hosts of SARS-CoV-2 } & Very unconfident & 9 & 1.5 & $3.9 \pm 0.9$ \\
\hline & Fairly unconfident & 34 & 5.5 & \\
\hline & Neutral & 113 & 18.3 & \\
\hline & Fairly confident & 296 & 47.8 & \\
\hline & Very confident & 167 & 27.0 & \\
\hline \multirow[t]{5}{*}{ The transmission routes of COVID-19 } & Very unconfident & 8 & 1.3 & $4.3 \pm 0.8$ \\
\hline & Fairly unconfident & 20 & 3.2 & \\
\hline & Neutral & 46 & 7.4 & \\
\hline & Fairly confident & 264 & 42.6 & \\
\hline & Very confident & 281 & 45.4 & \\
\hline \multirow{5}{*}{$\begin{array}{l}\text { The infectiousness of asymptomatic } \\
\text { COVID-19 patients }\end{array}$} & Very unconfident & 11 & 1.8 & $4.2 \pm 0.9$ \\
\hline & Fairly unconfident & 18 & 2.9 & \\
\hline & Neutral & 68 & 11.0 & \\
\hline & Fairly confident & 234 & 37.8 & \\
\hline & Very confident & 288 & 46.5 & \\
\hline \multirow{5}{*}{ The symptoms of COVID-19 } & Very unconfident & 10 & 1.6 & $4.1 \pm 0.8$ \\
\hline & Fairly unconfident & 14 & 2.3 & \\
\hline & Neutral & 61 & 9.9 & \\
\hline & Fairly confident & 329 & 53.2 & \\
\hline & Very confident & 205 & 33.1 & \\
\hline \multirow{5}{*}{$\begin{array}{l}\text { Medical quarantine requirements for } \\
\text { COVID-19 }\end{array}$} & Very unconfident & 9 & 1.5 & $4.1 \pm 0.9$ \\
\hline & Fairly unconfident & 22 & 3.6 & \\
\hline & Neutral & 86 & 13.9 & \\
\hline & Fairly confident & 270 & 43.6 & \\
\hline & Very confident & 232 & 37.5 & \\
\hline \multirow[t]{5}{*}{ Susceptible population of COVID-19 } & Very unconfident & 9 & 1.5 & $4.2 \pm 0.9$ \\
\hline & Fairly unconfident & 25 & 4.0 & \\
\hline & Neutral & 59 & 9.5 & \\
\hline & Fairly confident & 292 & 47.2 & \\
\hline & Very confident & 234 & 37.8 & \\
\hline \multirow[t]{5}{*}{ Inactivation methods of SARS-CoV-2 } & Very unconfident & 10 & 1.6 & $4.0 \pm 0.9$ \\
\hline & Fairly unconfident & 31 & 5.0 & \\
\hline & Neutral & 105 & 17.0 & \\
\hline & Fairly confident & 279 & 45.1 & \\
\hline & Very confident & 194 & 31.3 & \\
\hline \multirow{5}{*}{$\begin{array}{l}\text { The availability of specific drugs and } \\
\text { vaccines for COVID-19 }\end{array}$} & Very unconfident & 19 & 3.1 & $3.9 \pm 1.0$ \\
\hline & Fairly unconfident & 37 & 6.0 & \\
\hline & Neutral & 102 & 16.5 & \\
\hline & Fairly confident & 263 & 42.5 & \\
\hline & Very confident & 198 & 32.0 & \\
\hline
\end{tabular}

Bold values represent the largest proportion in the corresponding part.

Cognition and behavior changes before and after government measures were assessed by two questions about 1) changes in cognition and behavior of the epidemic before and after the strict exit screening measures and public health level 1 response of 31 provinces from January 23, 2020 on, and 2) changes in cognition and behavior of the epidemic before and after the upgraded measures from January 30, 2020 on.

The eight items on the knowledge dimension were assessed using a five-point Likert scale ranging from 1 to $5(1=$ very unconfident, 2 = fairly unconfident, 3 = neutral, 4 = fairly confident, and $5=$ very confident). Higher scores represented better knowledge. The six items on the attitude dimension were evaluated on a five-point Likert scale ranging from 1 to 5 ( 1 = strongly disagree, 2 = disagree, 3 = neither agree nor disagree/do not know, 4 = agree, and 5 = strongly agree). Higher scores indicated a more positive attitude. The 10 items on the practice dimension were scored on a five-point Likert scale ranging from 1 to $5(1=$ never, $2=$ seldom, $3=$ sometimes, 4 = often, and 5 = always). The five items on the barrier dimension were scored on a two-point scale ( 1 = yes and $0=$ no). The two items on the cognition and behavior change dimension were scored on a five-point Likert scale ranging from 1 to 5 ( 1 = absolutely unchanged, 2 = fairly unchanged, $3=$ neutral, $4=$ fairly changed, and $5=$ absolutely changed).

The final score for each scale was calculated by adding up the points obtained for the corresponding questions. The total score was the sum of the perceived knowledge score, attitude score, and practice score. Higher scores represented more active behavior (Supplemental Appendix 1).

Statistical analysis. An Excel sheet was automatically generated from the online questionnaire, allowing to perform the statistical analyses. Statistical analyses were performed using IBM SPSS Statistics 23.0. Descriptive statistical analysis was used to summarize the respondents' demographic characteristics. Two-sided statistical tests were used; chi-square test was for dichotomous or multinomial qualitative variables, whereas the Student's $t$-test was used to check for an association between continuous and dichotomous variables. The ANOVA test was used to compare multiple group means. Linear 
TABLE 3

Scores of attitude $(N=619)$

\begin{tabular}{|c|c|c|c|c|}
\hline Detailed questions about attitude & Categories & $N$ & $\%$ & $\mathrm{M} \pm \mathrm{SD}$ \\
\hline \multirow[t]{5}{*}{ Keep updated about COVID-19 } & Strongly disagree & 10 & 1.6 & $4.2 \pm 0.9$ \\
\hline & Disagree & 12 & 1.9 & \\
\hline & Neither agree nor disagree/do not know & 82 & 13.2 & \\
\hline & Agree & 267 & 43.1 & \\
\hline & Strongly agree & 248 & 40.1 & \\
\hline \multirow[t]{5}{*}{ Willing to learn more about COVID-19 } & Strongly disagree & 8 & 1.3 & $4.3 \pm 0.8$ \\
\hline & Disagree & 9 & 1.5 & \\
\hline & Neither agree nor disagree/do not know & 73 & 11.8 & \\
\hline & Agree & 245 & 39.6 & \\
\hline & Strongly agree & 284 & 45.9 & \\
\hline \multirow{5}{*}{$\begin{array}{l}\text { Ready for strong supports and active } \\
\text { cooperation in the prevention and } \\
\text { control for COVID-19 }\end{array}$} & Strongly disagree & 9 & 1.5 & $4.5 \pm 0.8$ \\
\hline & Disagree & 9 & 1.5 & \\
\hline & Neither agree nor disagree/do not know & 33 & 5.3 & \\
\hline & Agree & 193 & 31.2 & \\
\hline & Strongly agree & 375 & 60.6 & \\
\hline \multirow{5}{*}{$\begin{array}{l}\text { The outbreak of COVID-19 deserves } \\
\text { serious attention }\end{array}$} & Strongly disagree & 9 & 1.5 & $4.5 \pm 0.8$ \\
\hline & Disagree & 9 & 1.5 & \\
\hline & Neither agree nor disagree/do not know & 29 & 4.7 & \\
\hline & Agree & 173 & 27.9 & \\
\hline & Strongly agree & 399 & 64.5 & \\
\hline \multirow{5}{*}{$\begin{array}{l}\text { Aware of the designated hospitals in your } \\
\text { area }\end{array}$} & Strongly disagree & 13 & 2.1 & $4.2 \pm 0.9$ \\
\hline & Disagree & 21 & 3.4 & \\
\hline & Neither agree nor disagree/do not know & 77 & 12.4 & \\
\hline & Agree & 218 & 35.2 & \\
\hline & Strongly agree & 290 & 46.8 & \\
\hline \multirow{5}{*}{$\begin{array}{l}\text { Have full confidence in the government's } \\
\text { interventional measures }\end{array}$} & Strongly disagree & 9 & 1.5 & $4.5 \pm 0.8$ \\
\hline & Disagree & 7 & 1.1 & \\
\hline & Neither agree nor disagree/do not know & 47 & 7.6 & \\
\hline & Agree & 188 & 30.4 & \\
\hline & Strongly agree & 368 & 59.5 & \\
\hline
\end{tabular}

Bold values represent the largest proportion in the corresponding part.

regressions were conducted taking different scale scores as the dependent variables and sociodemographic characteristics as independent variables. $P<0.05$ was considered as significant.

\section{RESULTS}

Sociodemographic results. Eight hundred netizens were randomly chosen via Sina microblog platform; 619 (77.4\%) completed the online survey. The data of demographic characteristics (Table 1) indicated that, among the participants surveyed, $59.9 \%$ were female, $61.1 \%$ were aged from 18 to 30 years, $40.7 \%$ were living in villages, $34.1 \%$ were students, $50.2 \%$ were married, $42.3 \%$ had an undergraduate's degree, and $37.8 \%$ had a family of four members.

Scores of each scale. Scores of perceived knowledge. The results of Table 2 showed that 296 (47.8\%) of 619 respondents were fairly confident about the level of knowledge regarding the possible hosts of SARS-CoV-2, 281 (45.4\%) were very confident about the transmission routes of COVID-19, 288 (46.5\%) knew well about the infectiousness of asymptomatic COVID-19 patients, 329 (53.2\%) were fairly confident about the symptoms of COVID-19, 270 (43.6\%) were fairly confident about medical quarantine requirements for COVID-19, 292 (47.2\%) were fairly confident about susceptible population of COVID-19, 279 (45.1\%) were fairly confident about the inactivation methods of SARS-CoV-2, and 263 (42.5\%) were fairly confident about the availability of specific drugs and vaccines for COVID-19.

Scores of attitude. Table 3, the scores of attitude, showed that $267(43.1 \%)$ of 619 respondents agreed to keep updated about COVID-19, 284 (45.9\%) strongly agreed to be willing to learn more about COVID-19, 375 (60.6\%) strongly agreed to be ready for strong supports and active cooperation in the prevention and control for COVID-19, 399 (64.5\%) strongly agreed that the outbreak of COVID-19 deserved serious attention, 290 (46.8\%) were fully aware of the designated hospitals in the living area, and 368 (59.5\%) had full confidence in the government's interventional measures.

Scores of practice. The findings of Table 4, practice survey results, as reported by the participants, showed that 472 (76.3\%) respondents always wore a mask when going out in a correct way; 351 (56.7\%) always washed hands frequently and correctly; 420 (67.9\%) always covered the nose and mouth with hands when sneezing or coughing; 469 (75.8\%) always avoided meeting and gathering; 214 (34.6\%) often took physical exercise; 271 (43.8\%) often had a balanced and nutritious diet , with less or no consumption of wild animals; 427 (69.0\%) always avoided contact with live poultry; 287 (46.4\%) often got enough sleep; and 382 (61.7\%) would always go to the designated hospital immediately for medical treatment in case of suspected symptoms.

Scores of cognition and behavior changes. The results of Table 5 revealed that $318(51.4 \%)$ respondents had fairly changed cognition and behavior of the epidemic before and after the strict exit screening measures and public health level 1 response of 31 provinces from January 23, 2020 on; 286 (46.2\%) respondents experienced fairly changed cognition and behavior of the epidemic before and after the upgraded measures from January 30, 2020 on.

Overall evaluation. The results of Figure 1 (Supplemental Appendix 2) showed that 367 (59.29\%) of 619 respondents had very good knowledge, attitude, and behavior toward 
TABLE 4

Scores of practice $(N=619)$

\begin{tabular}{|c|c|c|c|c|}
\hline Detailed questions about practice & Categories & $N$ & $\%$ & $\mathrm{M} \pm \mathrm{SD}$ \\
\hline \multicolumn{5}{|l|}{$\begin{array}{l}\text { The frequency of the following behaviors } \\
\text { after the outbreak }\end{array}$} \\
\hline \multirow{5}{*}{$\begin{array}{l}\text { Wear a mask when going out in a } \\
\text { correct way }\end{array}$} & Never & 2 & 0.3 & \multirow[t]{5}{*}{$4.7 \pm 0.6$} \\
\hline & Seldom & 2 & 0.3 & \\
\hline & Sometimes & 16 & 2.6 & \\
\hline & Often & 127 & 20.5 & \\
\hline & Always & 472 & 76.3 & \\
\hline \multirow[t]{5}{*}{ Wash hands frequently and correctly } & Never & 2 & 0.3 & \multirow[t]{5}{*}{$4.5 \pm 0.7$} \\
\hline & Seldom & 2 & 0.3 & \\
\hline & Sometimes & 53 & 8.6 & \\
\hline & Often & 211 & 34.1 & \\
\hline & Always & 351 & 56.7 & \\
\hline Cover your nose and mouth with your & Never & 2 & 0.3 & \multirow[t]{5}{*}{$4.6 \pm 0.6$} \\
\hline \multirow{4}{*}{ hands when you sneeze or cough } & Seldom & 3 & 0.5 & \\
\hline & Sometimes & 26 & 4.2 & \\
\hline & Often & 168 & 27.1 & \\
\hline & Always & 420 & 67.9 & \\
\hline \multirow[t]{5}{*}{ Avoid meeting and gathering } & Never & 2 & 0.3 & \multirow[t]{5}{*}{$4.7 \pm 0.6$} \\
\hline & Seldom & 5 & 0.8 & \\
\hline & Sometimes & 11 & 1.8 & \\
\hline & Often & 132 & 21.3 & \\
\hline & Always & 469 & 75.8 & \\
\hline \multirow[t]{5}{*}{ Take physical exercise } & Never & 12 & 1.9 & \multirow[t]{5}{*}{$3.8 \pm 1.0$} \\
\hline & Seldom & 40 & 6.5 & \\
\hline & Sometimes & 185 & 29.9 & \\
\hline & Often & 214 & 34.6 & \\
\hline & Always & 168 & 27.1 & \\
\hline \multirow{5}{*}{$\begin{array}{l}\text { Have a balanced and nutritious } \\
\text { diet, with less or no consumption } \\
\text { of wild animals }\end{array}$} & Never & 1 & 0.2 & \multirow[t]{5}{*}{$4.1 \pm 0.8$} \\
\hline & Seldom & 12 & 1.9 & \\
\hline & Sometimes & 117 & 18.9 & \\
\hline & Often & 271 & 43.8 & \\
\hline & Always & 218 & 35.2 & \\
\hline \multirow[t]{5}{*}{ Avoid contact with live poultry } & Never & 3 & 0.5 & \multirow[t]{5}{*}{$4.6 \pm 0.6$} \\
\hline & Seldom & 2 & 0.3 & \\
\hline & Sometimes & 25 & 4.0 & \\
\hline & Often & 162 & 26.2 & \\
\hline & Always & 427 & 69.0 & \\
\hline \multirow{5}{*}{$\begin{array}{l}\text { Pay attention to household hygiene } \\
\text { and disinfection }\end{array}$} & Never & 1 & 0.2 & \multirow[t]{5}{*}{$4.3 \pm 0.7$} \\
\hline & Seldom & 6 & 1.0 & \\
\hline & Sometimes & 70 & 11.3 & \\
\hline & Often & 255 & 41.2 & \\
\hline & Always & 287 & 46.4 & \\
\hline \multirow[t]{5}{*}{ Get enough sleep } & Never & 5 & 0.8 & \multirow[t]{5}{*}{$4.2 \pm 0.8$} \\
\hline & Seldom & 14 & 2.3 & \\
\hline & Sometimes & 67 & 10.8 & \\
\hline & Often & 287 & 46.4 & \\
\hline & Always & 246 & 39.7 & \\
\hline Immediately go to the designated & Never & 5 & 0.8 & $4.5 \pm 0.7$ \\
\hline hospital for medical treatment in & Seldom & 6 & 1.0 & \\
\hline \multirow[t]{3}{*}{ case of suspected symptoms } & Sometimes & 42 & 6.8 & \\
\hline & Often & 184 & 29.7 & \\
\hline & Always & 382 & 61.7 & \\
\hline
\end{tabular}

COVID-19, followed by $163(26.33 \%)$ respondents with excellent, 79 (12.76\%) good, six $(0.97 \%)$ fair, and four $(0.65 \%)$ poor.

Barrier. For those who did not reach the very good or excellent level (89 participants), the main reasons included limited knowledge $(44,49.4 \%)$, influenced by the surrounding population $(36,40.4 \%)$, limited or no access to COVID-19 information $(31,34.8 \%)$, and attaching little importance to the outbreak (29, 32.6\%), as is shown in Table 6.

Score calculations and correlation. The calculated scores are summarized in Table 7 . The mean scores for each scale were as follows: perceived knowledge $(36.3 \pm 6.1)$, attitude $(29.4 \pm 4.7)$, practice $(44.1 \pm 4.8)$, total score $(109.7 \pm 13.2)$, barrier $(0.2 \pm 0.7)$, and cognition and behavior change score $(8.5 \pm 1.4)$.
Based on Table 8, better perceived knowledge was significantly associated with better attitude $(r=0.8)$, practice $(r=$ $0.5)$, total score $(r=0.9)$, cognition and behavior change score $(r=0.3)$, and lower barrier score $(r=-0.2)$. Better attitude was significantly associated with better practice $(r=0.5)$, better total score $(r=0.9)$, cognition and behavior change score $(r=$ $0.3)$, and lower barrier score $(r=-0.2)$. Better practice was significantly associated with better total score $(r=0.7)$, cognition and behavior change score $(r=0.3)$, and lower barrier score $(r=-0.2)$. Better total score was significantly associated with better cognition and behavior change score $(r=0.4)$ and lower barrier score $(r=-0.2)$. Better cognition and behavior change score was significantly associated with lower barrier score $(r=-0.3)$. 
TABLE 5

Scores of cognition and behavior changes $(N=619)$

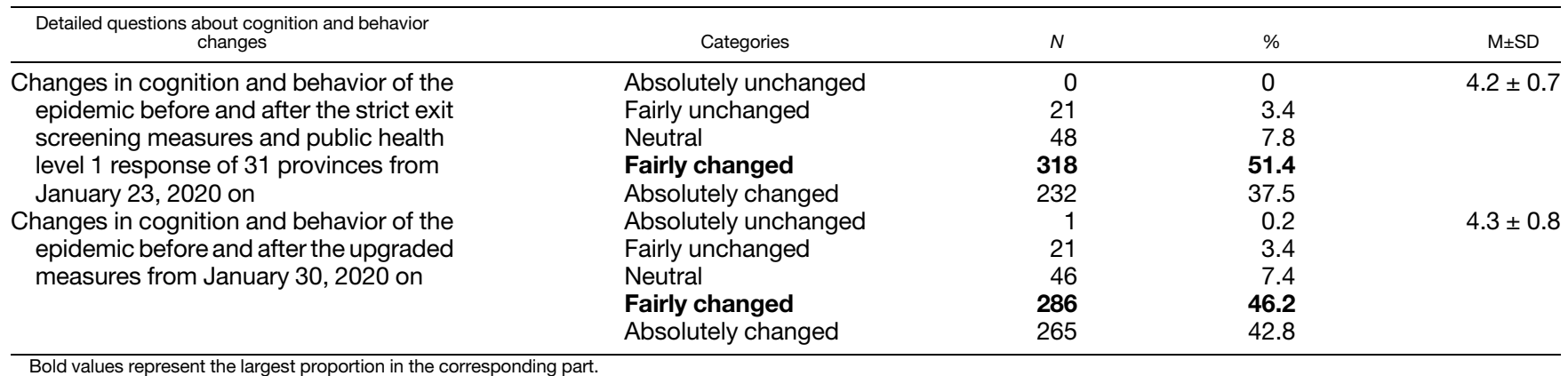

Bivariate analysis of factors associated with scores. The results of the bivariate analyses of factors associated with each score are shown in Table 9. A higher mean perceived knowledge score was associated with medical professionals and post-undergraduate degree, so was the attitude score and the total score. For the practice score, a higher mean practice score was associated with age $<18$ years, living in city, medical professionals, and post-undergraduate degree. For the barrier score, a higher mean practice score was associated with male and farmers. A higher mean cognition and behavior change score was associated with company employees.

Multivariable linear regressions. Multivariable linear regressions took each scale score as the dependent variable and the sociodemographic characteristics as independent variables. Dummy variables were used non-dichotomously in the linear regressions. For age, $>60$ years was set as the control group; for living district, village was set as the control group; for occupation, others was set as the control group; and for level of education, primary school or below was set as the control group.

Table 10, consisting of five linear regressions, summarized the factors associated with the same dependent variables, taking the sociodemographic variables as independent variables.

Linear regression 1, taking the perceived knowledge score as the dependent variable, showed that medical professionals (standardized beta 0.1 ), civil servants, employees of stateowned enterprises and public institutions, and company employees were associated with a higher perceived knowledge score. Junior college, undergraduate, and post-undergraduate (standardized beta 0.6) were associated with a higher perceived knowledge score.

Linear regression 2, taking the attitude score as the dependent variable, suggested that medical professionals (standardized beta 0.1), civil servants, employees of stateowned enterprises and public institutions, and company employees were associated with a higher attitude score. Senior high school/technical secondary school, junior college, undergraduate, and post-undergraduate (standardized beta 0.6 ) were associated with a higher attitude score.

Linear regression 3 , taking the practice score as the dependent variable, indicated that age $<18,18-30$ (standardized beta 0.5 ), $31-40,41-50$, and 51-60 years were associated with a higher practice score. City and town (standardized beta 0.0 ) were associated with higher practice scores. Medical professionals, civil servants, employees of state-owned enterprises and public institutions, self-employed, retired staff (standardized beta 0.1), and students were associated with higher practice scores. Senior high school/technical secondary school, junior college (standardized beta 0.2), and undergraduate were associated with a higher practice score.

Linear regression 4, taking the total score as the dependent variable, indicated that medical professionals (standardized beta 0.1 ), civil servants, employees of state-owned enterprises and public institutions, company employees, and retired staff were associated with a higher total score. Senior high school/technical secondary school, junior college, undergraduate, and post-undergraduate (standardized beta 0.6) were associated with a higher total score.

Linear regression 5 , taking the barrier score as the dependent variable, showed that males (standardized beta 0.2) and farmers (standardized beta 0.2) were associated with a higher barrier score.

Ways for obtaining information of COVID-19. The results of Supplemental Appendix 3 showed that the ways for obtaining information of COVID-19 included We-Chat and microblog (565, 28.3\%); radio and television (451, 22.6\%); family, friends, villagers, and community workers $(415,20.8 \%)$; websites (395, $19.8 \%)$; newspaper and periodicals (149, 7.5\%); and others $(19,1.0 \%)$.

Expectation about government measures. The results of residents' expectation about government measures (Supplemental Appendix 4) showed that 234 participants (37.8\%) believed the epidemic could be controlled in 2-3 months (excluding 3 months), and 160 participants (25.8\%) believed the epidemic could be controlled in 3-4 months (excluding 4 months).

\section{DISCUSSION}

As suggested by the $\mathrm{WHO}$, public cooperation is crucial in containing the spread of the outbreak and fighting against the pandemic calls for sustained efforts and constant vigilance. ${ }^{17,18}$ Therefore, the evaluation of public awareness and behavior is of great importance. Our investigation involved the perceived knowledge, attitude, practice, cognition, and behavior changes; overall evaluation; barrier; expectation about the government interventions; and ways of obtaining information about COVID-19.

First, the results showed that the majority of respondents (74.8-88.0\%) were fairly or very confident about the level of knowledge. As for the attitude scale, the majority of respondents (82.0-92.4\%) agreed or strongly agreed to hold a positive attitude toward the COVID-19 pandemic. They held the 
TABLE 6

Barriers

\begin{tabular}{|c|c|c|c|c|}
\hline & & \multicolumn{2}{|c|}{ Responses } & \multirow[b]{2}{*}{ Percent of cases } \\
\hline & & N & Percent & \\
\hline \multirow[t]{5}{*}{ Barriers } & S1. Limited knowledge & 44 & 29.9 & 49.4 \\
\hline & $\begin{array}{l}\text { S2. Attaching little importance to the } \\
\text { outbreak }\end{array}$ & 29 & 19.7 & 32.6 \\
\hline & $\begin{array}{l}\text { S3. Limited or no access to COVID-19 } \\
\text { information }\end{array}$ & 31 & 21.1 & 34.8 \\
\hline & $\begin{array}{l}\text { S4. Influenced by the surrounding } \\
\text { population (family, friends, colleagues, } \\
\text { classmates, etc.) }\end{array}$ & 36 & 24.5 & 40.4 \\
\hline & S5. Others & 7 & 4.8 & 7.9 \\
\hline Total & & 147 & 100.0 & 165.2 \\
\hline
\end{tabular}

opinion that the outbreak deserved serious attention and had full confidence in the government's interventions. For the practice scale, there was also a majority of respondents (79.0-97.1\%) reporting to be cautious in the prevention. Yet, there was a relatively low response rate of taking physical exercise $(61.7 \%)$, probably due to the social distancing and household quarantine policy. For the scale of cognition and behavior changes, a majority of respondents (88.9\%, 89.0\%) had fair or absolute changes before and after the initial strict control measures and the upgraded measures; $85.6 \%$ respondents had excellent or very good overall evaluation toward COVID-19. The main reasons for barrier lay in limited knowledge $(49.4 \%)$, influenced by the surrounding population(40.4\%), limited or no access to COVID-19 information $(34.8 \%)$, and attaching little importance to the outbreak $(32.6 \%)$. The findings of a high knowledge, attitude, and practice rate of COVID-19 in Chinese residents were expected, because four-phase stringent measures were implemented by Chinese health authorities, starting on January 23 , $2020 .^{8}$ Faced with the massive public health crisis, overwhelming news reports were delivered to the public by all kinds of media such as We-Chat, microblog, website, TV, and radio. According to the 45th China Statistical Report on Internet Development, ${ }^{19}$ of the total population of 1.4 billion, the number of netizens in China has exceeded 900 million, with an average of 30.8 online hours per week, so most people could get timely access to the updates about the disease and had a clear understanding of the information. The series of measures included public health level 1 response of 31 provinces, strict exit screening, larger scale of cancellation of mass gatherings, postponing schools, social distancing, and spontaneous household quarantine by citizens. During the time of spontaneous household quarantine, instead of going out as usual, people stayed at home as much as possible in case of being infected, which may account for the relatively low response rate of taking physical exercise.

Moreover, our analyses revealed that perceived knowledge, attitude, practice, total score, and cognition and behavior changes were significantly and positively correlated, whereas barrier was negatively correlated with those scales. Higher perceived knowledge was proved to be significantly associated with positive attitude and behavior. These findings clearly demonstrated the importance of improving residents' knowledge of COVID-19 through health education, which may also lead to an improvement in their attitudes and practices toward COVID-19. Besides, our findings revealed that the main ways for obtaining information of COVID-19 included We-Chat and microblog; radio and television; family, friends, villagers, and community workers; and websites. This could be used as evidence for the publicity routes for the government. Furthermore, the study also showed that those respondents who were medical professionals, civil servants, employees of state-owned enterprises and public institutions, and had higher level of education were associated with a higher perceived knowledge score, attitude score, practice score and total score, whereas those who had a lower level of education were associated with a higher barrier score; this was particularly true for male farmers. This could be explained by the facts that highly educated people tend to seek information more intuitively and have a better understanding of knowledge, whereas those who are less educated are more likely to meet with difficulties in equipping themselves with up-to-date information. Therefore, it is urgent to carry out health education for people with low education background. This can be enlightening and exploited as useful evidence for the guidance for health education of epidemic-both nationwide publicity and focusing on the target undereducated population by means of We-Chat, microblog, website, community workers, and so on.

TABLE 7

Description of the generated scores

\begin{tabular}{lcccccc}
\hline & Perceived knowledge score & Attitude score & Practice score & Total score & Barrier score & Cognition and behavior change score \\
\hline Mean & 36.3 & 29.4 & 44.1 & 109.7 & 0.2 & 8.5 \\
Median & 37.0 & 30.0 & 45.0 & 111.0 & 0.0 & 8.0 \\
SD & 6.2 & 4.7 & 4.8 & 13.2 & 0.7 & 1.4 \\
Variance & 37.7 & 21.8 & 22.7 & 174.2 & 0.5 & 2.0 \\
Minimum & 11.0 & 8.0 & 26.0 & 60.0 & 0.0 & 3.0 \\
Maximum & 45.0 & 35.0 & 50.0 & 130.0 & 4.0 & 10.0 \\
\hline
\end{tabular}


TABLE 8

Pearson's correlation between each score

\begin{tabular}{|c|c|c|c|c|c|c|c|}
\hline & & $\begin{array}{l}\text { Perceived knowledge } \\
\text { score }\end{array}$ & $\begin{array}{l}\text { Attitude } \\
\text { score }\end{array}$ & $\begin{array}{l}\text { Practice } \\
\text { score }\end{array}$ & $\begin{array}{l}\text { Total } \\
\text { score }\end{array}$ & $\begin{array}{l}\text { Barrier } \\
\text { score }\end{array}$ & $\begin{array}{l}\text { Cognition and behavior } \\
\text { change score }\end{array}$ \\
\hline \multirow[t]{2}{*}{ Perceived knowledge score } & r & 1 & $0.8^{\star}$ & $0.5^{\star}$ & $0.9^{\star}$ & $-0.2^{*}$ & $0.3^{*}$ \\
\hline & $P$-value & - & $<0.001$ & $<0.001$ & $<0.001$ & $<0.001$ & $<0.001$ \\
\hline \multirow[t]{2}{*}{ Attitude score } & $R$ & - & 1 & $0.5^{\star}$ & $0.9^{\star}$ & $-0.2^{\star}$ & $0.3^{*}$ \\
\hline & $P$-value & - & - & $<0.001$ & $<0.001$ & $<0.001$ & $<0.001$ \\
\hline \multirow[t]{2}{*}{ Practice score } & r & - & - & 1 & $0.7^{\star}$ & $-0.2^{\star}$ & $0.3^{*}$ \\
\hline & $P$-value & - & - & - & $<0.001$ & $<0.001$ & $<0.001$ \\
\hline \multirow[t]{2}{*}{ Total score } & r & - & - & - & 1 & $-0.2^{\star}$ & $0.4^{*}$ \\
\hline & $P$-value & - & - & - & - & $<0.001$ & $<0.001$ \\
\hline \multirow[t]{2}{*}{ Barrier score } & $r$ & - & - & - & & 1 & $-0.3^{\star}$ \\
\hline & $P$-value & - & - & - & - & - & $<0.001$ \\
\hline \multirow{3}{*}{$\begin{array}{l}\text { Cognition and behavior } \\
\text { change score }\end{array}$} & $r$ & - & - & - & - & - & - \\
\hline & $P$-value & - & - & - & - & - & - \\
\hline & - & - & - & - & - & - & - \\
\hline
\end{tabular}

${ }^{*}$ Correlation is significant at the 0.01 level (2-tailed).

What is more, it was interesting to identify that a higher mean cognition and behavior change score was associated with company employees. For this population, they were able to be well aware of the outbreak, but without the all-round publicity and initiative, they may not be supportive and spontaneously adherent to the desired health behaviors. The publicity of national prevention and control measures had the greatest impact on enterprise personnel. The second biggest impact was on the group of medical professionals, civil servants, and employees of state-owned enterprises and public institutions because they had the career awareness or professional literacy to fully understand the intervention policy

TABLE 9

Bivariate analysis of factors associated with scores

\begin{tabular}{|c|c|c|c|c|c|c|}
\hline & $\begin{array}{l}\text { Perceived knowledge } \\
\text { score }\end{array}$ & Attitude score & Practice score & Total score & Barrier score & $\begin{array}{l}\text { Cognition and behavior } \\
\text { change score }\end{array}$ \\
\hline \multicolumn{7}{|l|}{ Gender } \\
\hline Male & $35.9 \pm 6.3$ & $29.1 \pm 4.7$ & $44.2 \pm 5.0$ & $109.2 \pm 13.7$ & $0.3 \pm 0.8$ & $8.5 \pm 1.4$ \\
\hline Female & $36.5 \pm 6.0$ & $29.5 \pm 4.6$ & $44.1 \pm 4.6$ & $110.1 \pm 12.8$ & $0.2 \pm 0.6$ & $8.5 \pm 1.4$ \\
\hline$P$-value & 0.213 & 0.303 & 0.824 & 0.388 & 0.022 & 0.798 \\
\hline \multicolumn{7}{|l|}{ Age-group (years) } \\
\hline$<18$ & $35.7 \pm 7.1$ & $29.4 \pm 4.7$ & $45.3 \pm 4.8$ & $110.5 \pm 12.9$ & $0.2 \pm 0.8$ & $8.6 \pm 1.2$ \\
\hline $18-30$ & $36.3 \pm 6.0$ & $29.4 \pm 4.8$ & $44.2 \pm 4.5$ & $109.8 \pm 12.9$ & $0.2 \pm 0.6$ & $8.5 \pm 1.4$ \\
\hline $31-40$ & $37.2 \pm 6.4$ & $29.5 \pm 4.9$ & $44.5 \pm 5.3$ & $111.2 \pm 14.6$ & $0.3 \pm 0.8$ & $8.2 \pm 1.7$ \\
\hline $41-50$ & $36.5 \pm 5.7$ & $30.0 \pm 3.9$ & $44.2 \pm 4.9$ & $110.7 \pm 12.7$ & $0.3 \pm 0.8$ & $8.6 \pm 1.5$ \\
\hline $51-60$ & $35.9 \pm 6.8$ & $28.6 \pm 5.2$ & $43.8 \pm 5.0$ & $108.2 \pm 14.0$ & $0.2 \pm 0.7$ & $8.8 \pm 1.4$ \\
\hline$>60$ & $34.0 \pm 6.2$ & $27.6 \pm 3.9$ & $41.0 \pm 5.7$ & $102.7 \pm 14.8$ & $0.4 \pm 0.9$ & $7.9 \pm 1.2$ \\
\hline$P$-value & 0.420 & 0.277 & 0.025 & 0.123 & 0.841 & 0.080 \\
\hline \multicolumn{7}{|l|}{ Living district } \\
\hline City & $36.6 \pm 6.3$ & $29.7 \pm 4.9$ & $44.9 \pm 4.2$ & $111.2 \pm 13.2$ & $0.2 \pm 0.6$ & $8.6 \pm 1.5$ \\
\hline Town & $36.4 \pm 6.1$ & $29.3 \pm 4.8$ & $44.1 \pm 4.8$ & $109.7 \pm 13.1$ & $0.3 \pm 0.8$ & $8.4 \pm 1.4$ \\
\hline Village & $35.9 \pm 6.0$ & $29.1 \pm 4.4$ & $43.5 \pm 5.1$ & $108.5 \pm 13.2$ & $0.2 \pm 0.7$ & $8.5 \pm 1.3$ \\
\hline$P$-value & 0.403 & 0.477 & 0.004 & 0.084 & 0.186 & 0.407 \\
\hline \multicolumn{7}{|l|}{ Occupation } \\
\hline Medical professionals & $40.3 \pm 5.8$ & $31.6 \pm 4.6$ & $46.6 \pm 3.4$ & $118.5 \pm 11.1$ & $0.1 \pm 0.4$ & $8.8 \pm 1.3$ \\
\hline $\begin{array}{l}\text { Civil servants/employees of state- } \\
\text { owned enterprises/public institutions }\end{array}$ & $37.1 \pm 5.3$ & $30.4 \pm 4.1$ & $44.8 \pm 3.9$ & $112.3 \pm 11.3$ & $0.2 \pm 0.8$ & $8.8 \pm 1.5$ \\
\hline Company employees & $37.5 \pm 5.3$ & $30.2 \pm 4.2$ & $44.5 \pm 4.5$ & $112.2 \pm 12.5$ & $0.1 \pm 0.4$ & $8.8 \pm 1.3$ \\
\hline Workers & $34.8 \pm 5.7$ & $28.5 \pm 4.8$ & $43.1 \pm 4.2$ & $106.4 \pm 12.2$ & $0.3 \pm 0.8$ & $8.3 \pm 1.5$ \\
\hline Farmers & $33.7 \pm 7.0$ & $27.5 \pm 5.0$ & $40.9 \pm 6.5$ & $102.0 \pm 16.0$ & $0.6 \pm 1.0$ & $8.0 \pm 1.7$ \\
\hline Self-employed & $35.2 \pm 6.5$ & $28.8 \pm 5.1$ & $43.6 \pm 5.1$ & $107.7 \pm 14.8$ & $0.2 \pm 0.7$ & $8.6 \pm 1.5$ \\
\hline Retired staff & $35.8 \pm 6.9$ & $28.5 \pm 5.4$ & $44.2 \pm 4.2$ & $108.5 \pm 13.5$ & $0.3 \pm 0.9$ & $8.5 \pm 1.5$ \\
\hline Students & $36.2 \pm 6.0$ & $29.3 \pm 4.4$ & $44.3 \pm 4.6$ & $109.8 \pm 12.3$ & $0.2 \pm 0.6$ & $8.4 \pm 1.3$ \\
\hline Others & $35.2 \pm 6.6$ & $28.9 \pm 5.2$ & $44.5 \pm 4.8$ & $108.5 \pm 12.6$ & $0.1 \pm 0.3$ & $8.5 \pm 1.2$ \\
\hline$P$-value & $<0.001$ & 0.001 & $<0.001$ & $<0.001$ & 0.026 & 0.037 \\
\hline \multicolumn{7}{|l|}{ Level of education } \\
\hline Primary school or below & $32.3 \pm 5.7$ & $27.8 \pm 4.2$ & $40.8 \pm 6.0$ & $101.0 \pm 13.7$ & $0.2 \pm 0.6$ & $8.0 \pm 1.5$ \\
\hline Junior high school & $34.8 \pm 6.2$ & $29.1 \pm 4.1$ & $43.0 \pm 5.9$ & $106.9 \pm 13.8$ & $0.3 \pm 0.7$ & $8.5 \pm 1.5$ \\
\hline $\begin{array}{l}\text { Senior high school/technical } \\
\text { secondary school }\end{array}$ & $36.4 \pm 5.8$ & $28.9 \pm 4.5$ & $43.8 \pm 4.7$ & $109.1 \pm 12.2$ & $0.2 \pm 0.7$ & $8.8 \pm 1.1$ \\
\hline Junior college & $35.7 \pm 6.7$ & $29.1 \pm 5.0$ & $44.3 \pm 4.5$ & $109.1 \pm 13.4$ & $0.3 \pm 0.8$ & $8.4 \pm 1.3$ \\
\hline Undergraduate & $37.0 \pm 5.6$ & $29.6 \pm 4.6$ & $44.4 \pm 4.4$ & $111.0 \pm 12.6$ & $0.2 \pm 0.7$ & $8.5 \pm 1.5$ \\
\hline Post-undergraduate & $39.0 \pm 6.9$ & $31.8 \pm 5.5$ & $47.0 \pm 3.4$ & $117.8 \pm 13.1$ & $0.0 \pm 0.2$ & $9.0 \pm 1.0$ \\
\hline$P$-value & $<0.001$ & 0.049 & $<0.001$ & $<0.001$ & 0.590 & 0.104 \\
\hline
\end{tabular}
part. 
TABLE 10

Multivariable analyses: linear regressions

\begin{tabular}{|c|c|c|c|c|c|}
\hline \multirow{2}{*}{$\begin{array}{c}\text { Variable } \\
\text { Linear regression } 1 \text { taking the perceived knowledg }\end{array}$} & \multirow[t]{2}{*}{ Unstandardized beta } & \multirow[t]{2}{*}{ Standardized beta } & \multirow[t]{2}{*}{$P$-value } & \multicolumn{2}{|c|}{$\mathrm{Cl}$} \\
\hline & & & & & \\
\hline Medical professionals & 18.3 & 0.1 & $<0.001$ & 15.5 & 21.1 \\
\hline $\begin{array}{l}\text { Civil servants, and employees of state-owned } \\
\text { enterprises and public institutions }\end{array}$ & 7.5 & 0.0 & $<0.001$ & 5.4 & 9.7 \\
\hline Company employees & 3.6 & 0.0 & 0.001 & 1.5 & 5.7 \\
\hline Junior college & 33.2 & 0.3 & $<0.001$ & 30.9 & 35.4 \\
\hline Undergraduate & 32.4 & 0.5 & $<0.001$ & 30.8 & 34.0 \\
\hline Post-undergraduate & 31.9 & 0.6 & $<0.001$ & 30.4 & 33.4 \\
\hline \multicolumn{6}{|c|}{ Linear regression 2 taking the attitude score as the dependent variable } \\
\hline Medical professionals & 13.9 & 0.2 & $<0.001$ & 11.6 & 16.1 \\
\hline $\begin{array}{l}\text { Civil servants, and employees of state-owned } \\
\text { enterprises and public institutions }\end{array}$ & 6.6 & 0.1 & $<0.001$ & 4.8 & 8.3 \\
\hline Company employees & 2.7 & 0.0 & 0.002 & 1.0 & 4.4 \\
\hline Senior high school/technical secondary school & 27.2 & 0.3 & $<0.001$ & 25.1 & 29.3 \\
\hline Junior college & 26.7 & 0.3 & $<0.001$ & 24.6 & 28.2 \\
\hline Undergraduate & 26.5 & 0.5 & $<0.001$ & 25.2 & 27.7 \\
\hline Post-undergraduate & 25.4 & 0.6 & $<0.001$ & 24.2 & 26.6 \\
\hline \multicolumn{6}{|c|}{ Linear regression 3 taking the practice score as the dependent variable } \\
\hline$<18$ & 27.6 & 0.2 & $<0.001$ & 24.4 & 30.7 \\
\hline 18 to 30 & 26.6 & 0.5 & $<0.001$ & 24.2 & 29.0 \\
\hline 31 to 40 & 25.6 & 0.2 & $<0.001$ & 22.7 & 28.5 \\
\hline 41 to 50 & 24.8 & 0.2 & $<0.001$ & 22.0 & 27.6 \\
\hline 51 to 60 & 16.8 & 0.1 & $<0.001$ & 13.9 & 19.6 \\
\hline City & 1.7 & 0.0 & 0.008 & 0.4 & 2.9 \\
\hline Town & 2.0 & 0.0 & 0.003 & 0.7 & 3.3 \\
\hline Medical professionals & 10.7 & 0.1 & $<0.001$ & 8.3 & 13.0 \\
\hline $\begin{array}{l}\text { Civil servants, and employees of state-owned } \\
\text { enterprises and public institutions }\end{array}$ & 4.5 & 0.0 & $<0.001$ & 2.8 & 6.3 \\
\hline Self-employed & 2.9 & 0.0 & 0.002 & 1.0 & 4.8 \\
\hline Retired staff & 17.3 & 0.1 & $<0.001$ & 14.4 & 20.1 \\
\hline Students & 7.5 & 0.0 & $<0.001$ & 5.3 & 9.6 \\
\hline Senior high school/technical secondary school & 20.5 & 0.1 & $<0.001$ & 17.2 & 23.9 \\
\hline Junior college & 16.1 & 0.2 & $<0.001$ & 13.6 & 18.6 \\
\hline Undergraduate & 17.2 & 0.1 & $<0.001$ & 14.2 & 20.1 \\
\hline \multicolumn{6}{|c|}{ Linear regression 4 taking the total score as the dependent variable } \\
\hline Medical professionals & 54.9 & 0.1 & $<0.001$ & 47.5 & 62.3 \\
\hline $\begin{array}{l}\text { Civil servants, and employees of state-owned } \\
\text { enterprises and public institutions }\end{array}$ & 24.3 & 0.1 & $<0.001$ & 18.4 & 30.2 \\
\hline Company employees & 10.2 & 0.0 & $<0.001$ & 4.5 & 15.9 \\
\hline Retired staff & 7.5 & 0.0 & 0.022 & 1.1 & 14.0 \\
\hline Senior high school/technical secondary school & 103.5 & 0.3 & $<0.001$ & 96.6 & 110.3 \\
\hline Junior college & 104.4 & 0.4 & $<0.001$ & 98.7 & 110.1 \\
\hline Undergraduate & 103.9 & 0.5 & $<0.001$ & 100.1 & 107.6 \\
\hline Post-undergraduate & 100.1 & 0.6 & $<0.001$ & 96.7 & 103.5 \\
\hline \multicolumn{6}{|c|}{ Linear regression 5 taking the barrier score as the dependent variable } \\
\hline Male & 0.1 & 0.2 & $<0.001$ & 0.0 & 0.1 \\
\hline Farmers & 0.4 & 0.2 & $<0.001$ & 0.2 & 0.6 \\
\hline
\end{tabular}

and promote policy implementation by positive cooperation. The slightest impact was on the group of workers and farmers; the restricted level of knowledge hindered them from having a comprehensive understanding of the outbreak, even with the national publicity, so they had the lowest mean score of cognition and behavior change, suggesting further improvements on more effective measures for target population.

Last, more than half of the respondents(51.4\%) were optimistic about the government's prevention and control measures, believing the epidemic could be brought under control in 3 months (before 18 June). Based on the data from the National Health Commission of the People's Republic of China, ${ }^{20-23}$ from March 24, 2020 on, there were only occasional domestic new confirmed cases, indicating the plateaued situation of the epidemic and the shift of focusing on preventing the importing of exogenous cases. It turned out that the respondents' expectations were in line with the actual situation of epidemic control in China, which proved the effectiveness of government publicity and interventions.

Limited researches of knowledge, attitude, and practice investigation have been published, ${ }^{24-26}$ whose results were in accordance with the current study; that was, Chinese residents tended to have good knowledge, positive attitude, and supportive behavior during the outbreak of COVID-19. However, some different opinions existed in another crosssectional survey, which believed that the finding of a high correct rate of COVID-19 knowledge in Chinese residents was unexpected. That study was conducted from January 27 to February 1, the week immediately after the lockdown of Hubei Province when the public were still on the way of having a full picture of the virus. The positive results in the very early stage of the outbreak may be related to the immediate interventions. It was also interesting to find that the investigations of foreign countries like Pakistan ${ }^{27}$ and Nigeria $^{28}$ also showed an overall good result of knowledge, 
attitude, and practice, except that $52.1 \%$ of the respondents perceived that the government was not doing enough to curtail COVID-19 in Nigeria. ${ }^{27}$

The strength of this study lies in bringing in the cognition and behavior changes, overall evaluation, barrier, and expectations about the government interventions. By identifying the most beneficial group of publicity and the reasons for barrier, more target policies can be established and more scientific approaches can be adopted to facilitate the epidemic control. However, there are certain limitations to the study. First, although the sample size is enough for statistical analyses to be carried out, the results could have been more representative if a larger sample had been recruited for the cross-sectional survey. Although the number of netizens reaches more than 900 million, there are still a group of people who do not have access to or use social media, which restricts the coverage of the research. Because of the limited sample representativeness, we must be cautious when interpreting the findings of the research, and further study is needed to resolve the issue. Second, the relatively low response rates, the absence of validation of these surveys due to the special case of COVID19 , and the large number of statistical analyses may lead to a potential result bias; however, we have tried our best to enhance the study reliability and validity to make sure high quality data were obtained, and we are ready to make improvements in the future studies.

\section{CONCLUSION}

In summary, our findings suggest that the respondents in China had good knowledge, attitude, and practice toward COVID-19; however, it is advisable to both strengthen nationwide publicity and focus on the target undereducated population by means of WeChat, microblog, website, community workers, and so on.

Received May 9, 2020. Accepted for publication February 3, 2021.

Published online February 19, 2021.

Note: Supplemental Appendices appear at www.ajtmh.org.

Acknowledgments: We thank all the participants involved in this study for their cooperation and support. Publication charges for this article were waived due to the ongoing pandemic of COVID-19.

Authors' addresses: Yaqing Fang, Panpan Liu, and Qisheng Gao, School of Public Health, Hangzhou Medical College, Hangzhou, China, E-mails: colourwind1035@126.com, 165272885@qq.com, and281133802@ qq.com.

This is an open-access article distributed under the terms of the Creative Commons Attribution (CC-BY) License, which permits unrestricted use, distribution, and reproduction in any medium, provided the original author and source are credited.

\section{REFERENCES}

1. World Health Organization, 2020. Statement on the Second Meeting of the International Health Regulations. Available at: https://www.who.int/news-room/detail/30-01-2020-statementon-the-second-meeting-of-the-international-health-regulations(2005)-emergency-committee-regarding-the-outbreak-of-novelcoronavirus-(2019-ncov). Accessed April 12, 2020.

2. Kapoor A et al., 2020. Cardiovascular risks of hydroxychloroquine in treatment and prophylaxis of COVID-19 patients: a scientific statement from the Indian Heart Rhythm Society. Indian Pacing Electrophysiol J 20: 117-120.

3. World Health Organization, 2020. Coronavirus (COVID-19) Updates. Available at: https://who.sprinklr.com/. Accessed April 13, 2020.
4. National Health Commission of the People's Republic of China, 2020. Updates about COVID-19. Available at: http://www.nhc.gov.cn/xcs/ yqtb/202004/ee6750d722a54876872056e6aafd5822.shtml. Accessed April 13, 2020.

5. Chen $\mathrm{N}$ et al., 2020. Epidemiological and clinical characteristics of 99 cases of 2019 novel coronavirus pneumonia in Wuhan, China: a descriptive study. Lancet 395: 507-513.

6. Khafaie MA, Rahim F, 2020. Cross-country comparison of case fatality rates of COVID-19/SARS-COV-2. Osong Public Health Res Perspect 11: 74-80.

7. The Novel Coronavirus Pneumonia Emergency Response Epidemiology Team, 2020. The epidemiological characteristics of an outbreak of 2019 novel coronavirus diseases (COVID-19) in China. Chin J Epidemiol 41: 145-151.

8. Fang $Y$, Nie $Y$, Penny M, 2020. Transmission dynamics of the COVID-19 outbreak and effectiveness of government interventions: a data-driven analysis. J Med Virol 92: 1-15.

9. Zhou $\mathrm{M}$ et al., 2020. Knowledge, attitude and practice regarding COVID-19 among health care workers in Henan, China. $J$ Hosp Infect 105: 183-187.

10. Geldsetzer P, 2020. Use of rapid online surveys to assess people's perceptions during infectious disease outbreaks: a crosssectional survey on COVID-19. J Med Internet Res 22: e18790.

11. Bener A, Al-Khal A, 2004. Knowledge, attitude and practice towards SARS. J R Soc Promot Health 124: 167-170.

12. Aldohyan $M$ et al., 2019. The perceived effectiveness of MERSCoV educational programs and knowledge transfer among primary healthcare workers: a cross-sectional survey. BMC Infect Dis 19: 273.

13. Suen LJ, Huang HM, Lee HH, 2014. A comparison of convenience sampling and purposive sampling. Hu Li Za Zhi 61: 105-111.

14. Finance.sina.com.cn, 2020. Microblog Financial Report in the First Quarter of 2020: Active Users Reach 550 Million Monthly. Available at: http://finance.sina.com.cn/roll/2020-05-19/dociirczymk2482234.shtml. Accessed July 10, 2020.

15. Xu Y et al., 2019. Knowledge, attitude, and practice of healthcare professionals toward clinically applying graduated compression stockings: results of a Chinese web-based survey. J Thromb Thrombolysis 47: 102-108.

16. Hajj $A$ et al., 2019. Assessment of knowledge, attitude and practice among community pharmacists towards dentalcare: a national cross sectional survey. Saudi Pharm J 27: 475-483.

17. World Health Organization, 2020. WHO Director-General's Opening Remarks at the Mission Briefing on COVID-19. Availabl at: https://www.who.int/dg/speeches/detail/who-director-generals-opening-remarks-at-the-mission-briefing-on-covid-19. Accessed April 15, 2020.

18. World Health Organization, 2020. WHO Director-General's Opening Remarks at the Mission Briefing on COVID-19. Availabl at: https://www.who.int/dg/speeches/detail/who-director-generals-opening-remarks-at-the-media-briefing-on-covid-19---24february-2020. Accessed April 15, 2020.

19. Cyberspace Administration of China, 2020. The 45th China Statistical Report on Internet Development. Available at: http:// www.cac.gov.cn/2020-04/27/c_1589535470378587.htm. Accessed September 21, 2020.

20. National Health Commission of the People's Republic of China, 2020. Updates about the COVID-19 as of March 24th, 2020. Available at: http://www.nhc.gov.cn/xcs/yqtb/202003/ b882c06edf184fbf800d4c7957e02 dad.shtml. Accessed April 16,2020

21. National Health Commission of the People's Republic of China, 2020. Updates about the COVID-19 as of March 25th, 2020. Available at: http://www.nhc.gov.cn/xcs/yqtb/202003/ f01fc26a8a7b48debe194bd1277 fdba3.shtml. Accessed April 16,2020

22. National Health Commission of the People's Republic of China, 2020. Updates about the COVID-19 as of March 26th, 2020. Available at: http://www.nhc.gov.cn/xcs/yqtb/202003/c521093a01734df3b3fb c156064 ba19f.shtml. Accessed April 16, 2020.

23. National Health Commission of the People's Republic of China, 2020. Updates about the COVID-19 as of March 27th, 2020. Available at: http://www.nhc.gov.cn/xcs/yqtb/202003/bf66696029ba420098164 6072400 74f8.shtml. Accessed April 16, 2020. 
24. Chen $Y$ et al., 2020. The network investigation on knowledge, attitude and practice about COVID-19 of the residents in Anhui province. Zhonghua Yu Fang Yi Xue Za Zhi 54: 367-373.

25. Zhong BL et al., 2020. Knowledge, attitudes, and practices towards COVID-19 among Chinese residents during the rapid rise period of the COVID-19 outbreak: a quick online crosssectional survey. Int J Biol Sci 16: 1745-1752.

26. Lin $\mathrm{Y}, \mathrm{Hu} \mathrm{Z}$, Alias $\mathrm{H}$, Wong LP, 2020. Knowledge, attitudes, impact, and anxiety regarding COVID-19 infection among the public in China. Front Public Health 8: 236.
27. Hussain I, Majeed A, Imran I, Ullah M, Hashmi FK, Saeed H, Chaudhry MO, Rasool MF, 2020. Knowledge, attitude, and practices toward COVID-19 in primary healthcare providers: a cross-sectional study from three tertiary care hospitals of Peshawar, Pakistan. J Community Health. 2020 Jul 6: 1-9. doi: 10.1007/s10900-020-00879-9.

28. Reuben RC, Danladi MMA, Saleh DA, Ejembi PE, 2020. Knowledge, attitudes and practices towards COVID-19: an epidemiological survey in North-Central Nigeria. $J$ Community Health $1-14$. 